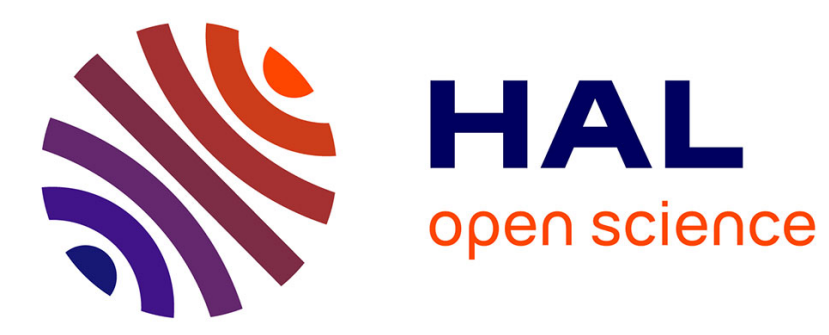

\title{
Differential phosphorylation of Cdc25C phosphatase in mitosis.
}

Jérôme Bonnet, Pauline Mayonove, May C Morris

\section{To cite this version:}

Jérôme Bonnet, Pauline Mayonove, May C Morris. Differential phosphorylation of Cdc25C phosphatase in mitosis.. Biochemical and Biophysical Research Communications, 2008, 370 (3), pp.483-8. 10.1016/j.bbrc.2008.03.117 . hal-00345928

\section{HAL Id: hal-00345928 \\ https://hal.science/hal-00345928}

Submitted on 21 Jan 2009

HAL is a multi-disciplinary open access archive for the deposit and dissemination of scientific research documents, whether they are published or not. The documents may come from teaching and research institutions in France or abroad, or from public or private research centers.
L'archive ouverte pluridisciplinaire HAL, est destinée au dépôt et à la diffusion de documents scientifiques de niveau recherche, publiés ou non, émanant des établissements d'enseignement et de recherche français ou étrangers, des laboratoires publics ou privés. 


\title{
Differential phosphorylation
}

\section{of Cdc25C phosphatase in mitosis}

\author{
Jérôme Bonnet*, Pauline Mayonove, and May C. Morris*\#
}

Université de Montpellier, CRBM-CNRS-UMR 5237, Interactions \& Molecular Mechanisms regulating Cell Cycle Progression, 1919 Route de Mende, 34293 Montpellier, IFR 122, France

*To whom correspondance should be addressed.

Email: jerome.bonnet@crbm.cnrs.fr and may.morris@crbm.cnrs.fr

\#Corresponding author: M.C. Morris: may.morris@crbm.cnrs.fr Tel : +33467613372; Fax : +33467521559 


\begin{abstract}
Cdc25 dual-specificity phosphatases coordinate entry into mitosis through activating dephosphorylation of the Mitosis-Promoting Factor, Cdk1-cyclin B1. Activation of Cdc25C at the G2/M transition, involves its dissociation from 14-3-3, together with its hyperphosphorylation on several sites within its regulatory $\mathrm{N}$-terminal domain, mediated by cyclin-dependent kinases and Plk1. Growing evidence suggests that phosphorylation intermediates are likely to precede complete hyperphosphorylation of Cdc25C. To address whether such variants occur in mitotic cells, we raised antibodies directed against different mitotic phosphorylation sites of human $\mathrm{Cdc} 25 \mathrm{C}$, and characterized the phosphorylated species detectable in HeLa cells. In the present study, we provide first-time evidence for the existence of multiple species of $\mathrm{Cdc} 25 \mathrm{C}$ in mitotic cell extracts, including full-length and splice variants with different phosphorylation patterns, thereby revealing an intricate network of $\mathrm{Cdc} 25 \mathrm{C}$ phosphatases, likely to have distinct biological functions.
\end{abstract}

Keywords: Cell cycle, mitosis, cdc25, phosphatase, phosphorylation, alternative splicing 


\section{$\underline{\text { Introduction }}$}

Transitions between the different phases of the mammalian cell cycle are driven by the sequential activation of cyclin-dependent kinases, whose activity is dictated by the periodic expression of cyclin subunits, and a number of posttranslational modifications [1]. In particular Cdc25 dualspecificity phosphatases coordinate entry into mitosis through activating dephosphorylation of the Mitosis-Promoting Factor, Cdk1-cyclin B1 [2]. In turn, active Cdk1-cyclin B1 establishes a positive feedback loop with Cdc25 phosphatases, contributing to their hyperactivation through phosphorylation of several S/T-P sites [3-7].

In human, three isoforms of Cdc25, A, B and C, cooperate in regulating cell cycle progression [8]. It is widely accepted that $\mathrm{Cdc} 25 \mathrm{~B}$ is responsible for initial activation of Cdk1-cyclin B1 at centrosomes, while Cdc25A and Cdc25C would be involved in further amplification of its activity [8-12]. Since its initial discovery as the first Cdc25 phosphatase, Cdc25C has been extensively characterized in terms of function and regulation [13, 14]. During interphase, phosphorylation of Cdc25C on Ser216 prevents its activation, by promoting its sequestration in the cytoplasm through association with 14-3-3 proteins [15-17]. At the G2/M transition, dissociation of Cdc25C from 143-3, together with its hyperphosphorylation on several sites within its regulatory N-terminal domain, Thr48, Thr67, Ser 122, Thr130 and Ser214, coincides with mitotic activation of Cdc25C [18-22]. Recent studies in Xenopus have revealed that Thr130 phosphorylation is a prerequisite to 14-3-3 dissociation [23-25]. Moreover, phosphorylation of human Cdc25C on Ser214 in mitosis has been shown to prevent re-phosphorylation of Ser216 and subsequent inactivation of Cdc25C through re-binding of 14-3-3 [18].

Hyperphosphorylation of $\mathrm{Cdc} 25 \mathrm{C}$ is readily detected in mitotic extracts due to a significant reduction in its electrophoretic mobility, first described in the literature for Xenopus Cdc25C [26]. However, it remains unclear whether phosphorylated intermediates of fully active Cdc25C occur in mitotic cells. Moreover, several studies report the identification of alternatively spliced variants of 
Cdc25C, namely Cdc25C1 (full length protein, $53 \mathrm{kDa})$ Cdc25C2 (48kDa), C3 (33 kDa) C4 (49 $\mathrm{kDa})$ and $\mathrm{C5}(42 \mathrm{kDa})$, some of which are upregulated in cancer cell types [27-31]. These splice variants diverge by some phosphorylation sites and regulatory interaction patches, suggesting that they are likely to integrate and respond to different regulatory inputs. However there is no evidence relating to phosphorylation of these splice variants. In this study, we have raised and purified antibodies that recognize specific phosphorylation sites of human $\mathrm{Cdc} 25 \mathrm{C}$, and have used these to probe for phosphorylated species of $\mathrm{Cdc} 25 \mathrm{C}$ in HeLa cell extracts. We have identified several phosphorylated forms of this phosphatase in mitotic HeLa extracts, providing first-time evidence for the occurrence of multiple phosphorylated Cdc25C species, including phosphorylated splice variants, thereby revealing the existence of a complex network of $\mathrm{Cdc} 25 \mathrm{C}$ isoforms.

\section{Materials and methods}

Cell culture, synchronization, and siRNA transfection. HeLa cells were cultured in DMEM supplemented with $10 \% \mathrm{FCS}$, at $37^{\circ} \mathrm{C}$ in an atmosphere containing $5 \% \mathrm{CO}_{2}$. Cell culture media, serum and antibiotics were purchased from Invitrogen. Cells were synchronized in mitosis for 12 hours with $250 \mu \mathrm{g} / \mathrm{ml}$ Nocodazole, and collected by mitotic shakeoff. siRNA smart-pools ${ }^{\mathrm{TM}}$ targeting Cdc25C and control siRNA (non targeting) were obtained from Dharmacon. 50nM siRNA were transfected twice at a $24 \mathrm{~h}$ interval with Oligofectamine ${ }^{\mathrm{TM}}$ (Invitrogen) according to the manufacturer's instructions. Cells were collected by trypsinization 72 hours after the first transfection, frozen in liquid nitrogen and stored at $-80^{\circ} \mathrm{C}$.

Immunization and purification of Cdc25C phosphospecific antibodies. All peptides derived from Cdc25C phosphorylation sites were synthesized by GL Biochem Shanghai Ltd (China). Rabbits were immunized with thyroglobulin-coupled pThr130, pThr48 and pSer214 peptides (CAQLLCSpTPNGLDRG, CVPRpTPVGKFLG and CGLYRpSPSMPELN, respectively) by the Animal Core Facility. Sera were first purified against phosphopeptides and then against the 
corresponding unphosphorylated peptides to eliminate all remaining non phospho-specific antibodies, on Sulfolink ${ }^{\mathrm{TM}}$ resin (Pierce, USA) as recommended by the manufacturer. Purified antibodies were concentrated by ammonium sulfate precipitation, dialyzed into PBS and stored at $20^{\circ} \mathrm{C}$ in $50 \%$ glycerol.

Western- blotting and antibodies. Cells were lysed in 50mM Tris, $150 \mathrm{mM} \mathrm{NaCl}, 0.1 \%$ NP40, $0.1 \%$ deoxycholate, 2mM EDTA, 1mM PMSF, Complete ${ }^{\mathrm{TM}}$ protease inhibitors (Roche), 50mM NaF, 40mM $\beta$-Glycero-phosphate, $1 \mathrm{mM} \mathrm{NaVO4}$., on ice and vortexed every $5 \mathrm{~min}$ for $30 \mathrm{~min}$, sonicated twice for 2 seconds at low intensity, then centrifuged at $17000 \mathrm{~g}$ at $4^{\circ} \mathrm{C}$. The soluble fraction was dosed by BCA assay (Pierce), and boiled in Laemmli buffer. For Lambda-phosphatase assays, cells synchronized with nocodazole were processed in the same fashion, treated with 400 Units Lambda phosphatase for $30 \mathrm{~min}$ at $30^{\circ} \mathrm{C}$ in buffer deprived of phosphatase inhibitors, and then boiled in Laemmli buffer. $30 \mu \mathrm{g}$ of total protein were loaded by lane and separated on $10 \%$ SDS-PAGE, then transferred onto a PVDF membrane (Perkin-Elmer). Protein loading was controlled by amido-black staining of the membrane (Sigma). Membranes were blocked in TBS 0, 1\% Tween 20, $5 \%$ non-fat dry milk for 1 hour. Antibodies against the C-terminus of Cdc25C (C-20, sc-327) were purchased from Tebu-Bio (Santa-Cruz). For Western blotting, all primary antibodies were used at a 1:500 dilution, incubated overnight at $4^{\circ} \mathrm{C}$ in TBS $0,1 \%$ Tween $20,5 \%$ non-fat dry milk except for phospho-specific antibodies which were incubated in TBS 0,1\% Tween 20, $3 \%$ BSA. Membranes were rinsed three times for 5 minutes in TBS-Tween $0,1 \%$, then incubated with secondary donkey anti-rabbit IgG, coupled to horseradish peroxydase (GE Healthcare) at a 1:10000 dilution in TBS $0,1 \%$ Tween $20,5 \%$ non-fat dry milk for 1 hour at room temperature. Western blots were revealed with the Western-Lightning ECL (Perkin-Elmer).

\section{$\underline{\text { Results }}$}

Characterization of human Cdc25C variants in interphasic and mitotic cells. 
In order to characterize the different species of Cdc25C present in interphasic and mitotic HeLa cells, we probed cell extracts by Western blotting with a generic antibody directed against the Cterminus of the phosphatase (C-20). We identified several forms of Cdc25C, which we classified into three categories, according to their electrophoretic mobility (Fig 1A). In asynchronous HeLa cell extracts, two major species of Cdc25C were detected: a doublet in the $60 \mathrm{kDa}$ range (molecular weight range 2), corresponding to full-length "interphasic" forms of $\mathrm{Cdc} 25 \mathrm{C}$, unphosphorylated and phosphorylated on Ser216, as well as bands with an apparent molecular weight of 45kDa (range 1), which are most likely Cdc25C splice variants Cdc25C5 (42kDa), Cdc25C2 or Cdc25C4 (around 48 $\mathrm{kDa}$ ). In mitotic cell extracts, although these forms are also detectable, the most abundant species are found around $80 \mathrm{kDa}$ (molecular weight range 3), inferring that these are hyperphosphorylated forms of Cdc25C. The specific identity of bands detected with the C-20 antibody, was verified by probing cell extracts from interphase and mitotic cells treated with siRNA targeting Cdc25C (or with non-targeting siRNA, as a control). Most of the bands detected by the C-20 antibody disappeared upon treatment with Cdc25C-specific siRNA, with the exception of a prominent band at $45 \mathrm{kDa}$, between the splice variants described above. Moreover, to verify whether the high molecular weight forms detected in mitotic cell extracts were indeed phosphorylated, cell extracts were treated with Lambda phosphatase, which lead to their complete disappearance, to the benefit of the $60 \mathrm{kDa}$ form (Fig1B).

\section{Cdc25C phospho-specific antibodies specifically recognize phosphoproteins with the same electrophoretic mobility as Cdc25C in mitotic cell extracts.}

To further characterize mitotic phosphorylation variants of $\mathrm{Cdc} 25 \mathrm{C}$, we raised and purified several antibodies against three different phosphopeptides derived from phosphorylation sites Thr48, Thr130, and Ser214, and used these antibodies to probe extracts from asynchronous (and therefore mostly interphasic) or mitotic HeLa cells (Fig. 2). Anti-Thr130 and anti-Ser214 antibodies only 
recognized proteins present in mitotic extracts. Moreover these bands completely disappeared after Lambda phosphatase treatment of mitotic extracts, indicating that these antibodies were truly phosphospecific (Fig 2A and 2B). Anti-pThr48 was somewhat less specific and detected several proteins in asynchronous cell extracts, but otherwise recognized phospho-specific bands in the mitotic extract, which were depleted upon Lambda phosphatase treatment (Fig 2C). Interestingly, the phosphoproteins detected with our phosphospecific antibodies exhibited similar electrophoretic mobilities to those detected by the C-20 antibody, therefore suggesting they were Cdc25C variants.

\section{Anti-phosphoCdc25C antibodies reveal the coexistence of multiple differentially phosphorylated forms of Cdc25C in mitosis, including splice variants.}

To rule out the possibility that our antibodies recognized phosphoproteins other than $\mathrm{Cdc} 25 \mathrm{C}$ with the same electrophoretic mobility, they were used to probe mitotic cell extracts treated with siRNA targeting Cdc25C, or control siRNA. All three antibodies revealed a net reduction in the intensity or a complete disappearance of the phosphoproteins bands upon siRNA treatment, thereby confirming that these antibodies specifically recognize Cdc25C phosphovariants in mitotic extracts (Fig 3). Anti-pThr130 detects two species: one in molecular weight range 2 and one in range 3 (Fig 3A). Anti-pSer214 recognizes five species depleted by siRNA : two in range 3, one in range 2, and two in range 1 (Fig. 3B). Anti-pThr 48 recognizes four to six variants of Cdc25C: two in range 2, at least two in range 3 appearing as a smeared band, and two in range 1, although the identity of the latter is questionable, as they are not significantly depleted upon siRNA treatment. In addition, antipSer214 and anti-pThr48 detect high molecular weight species, which are only quite partially depleted by siRNA treatment, and which most likely correspond to unrelated phosphoproteins which are non-specifically recognized by these antibodies, although we cannot completely exclude that they are hyperphosphorylated species of Cdc25C (Fig. 3B \& C, asterisk). However, it seems unlikely that $\mathrm{Cdc} 25 \mathrm{C}$ should undergo a change in electrophoretic mobility greater than $25 \mathrm{kDa}$ upon 
phosphorylation of five residues, and the extraction conditions used in this experiment do not preserve posttranslational modifications which might occur in concert with phosphorylation, such as ubiquitinylation or sumoylation. The species detected by all three antibodies with an apparent molecular weight of $60 \mathrm{kDa}$ probably correspond to monophosphorylated forms of Cdc $25 \mathrm{C}$, whereas species with reduced electrophoretic mobility are most likely phosphorylated on multiple sites. The forms detected by pSer214 and pThr48 with an apparent molecular weight of 45kDa are most likely Cdc25C splice variants detected with the C-20 antibody. Indeed, an alignment of the primary sequences of the different Cdc25C splice variants shows that they all harbour Thr48, Ser214 and Ser216, but neither Ser122 nor Thr130; moreover only C1, C2 and C3 splice variant retain Thr67, whereas C4 and C5 harbour a Ser instead (Fig. 3D). These findings infer an additional level of complexity in the network of $\mathrm{Cdc} 25$ phosphatases. A schematic model illustrating the variety of Cdc25C species which occur in mammalian cells, including multiple phosphorylation intermediates and splice variants, is represented in Fig. 4.

\section{$\underline{\text { Discussion }}$}

Mitotic hyperphosphorylation of $\mathrm{Cdc} 25 \mathrm{C}$ is associated with an increase in its phosphatase activity and is readily detected through a significant shift in its electrophoretic mobility [3, 15-20, 26]. Although it is commonly assumed that Cdc25C oscillates between an hypophosphorylated (Ser216 phosphorylated) inactive state, and a hyperphosphorylated active mitotic form, growing evidence suggests that intermediate phosphorylation variants are likely occur [18, 23-25]. To address this issue, we have raised antibodies against three different mitotic phosphorylation sites of human Cdc25C (Thr48, Thr130, Ser214), and have characterized the different phosphorylated species detectable in HeLa cell extracts. Whilst each of our antibodies reveals a different spectrum of Cdc25C variants, together they identify a complex network of phosphorylation intermediates, harbouring at least two forms of Cdc25C phosphorylated on Thr130, five on Ser214 and four-six 
forms phosphorylated on Thr48. Based on their electrophoretic mobility, we infer that these include intermediates bearing different combinations of multiple phosphorylated residues, as well as monoor bis-phosphorylated species, and phosphorylated splice variants. Hence, while mitotic phosphorylations of $\mathrm{Cdc} 25 \mathrm{C}$ are commonly believed to occur simultaneously, our data instead imply that intermediate phosphorylated forms occur independently, further inferring a specific biological function for these intermediates. Phosphorylation may regulate subcellular localization, interactions with different partners/substrates, or even influence the catalytic activity of Cdc25C per se. Further studies will be required to gain insight into the biological function of the phosphorylated species identified in this study.

An additional level of complexity in the biology of Cdc25 phosphatases was uncovered with the identification of alternatively spliced variants of all three Cdc25 phosphatases [27-34]. However, unlike Cdc25B splice variants, which have been extensively studied [32-34], the function and regulation of $\mathrm{Cdc} 25 \mathrm{C}$ splice variants remains largely unknown. The present study reveals that splice variants of Cdc25C are phosphorylated on Ser214 and possibly on Thr48 in mitosis, suggesting that they are subject to the same regulatory mechanisms as full-length Cdc25C. Phosphorylation of Ser214 has been shown to promote mitotic activation of Cdc25C, by preventing 14-3-3 binding [18], therefore implying that the phosphorylated Cdc25C5 and $\mathrm{C} 2 / \mathrm{C} 4$ splice variants identified in this study are also active during mitosis. Future studies will be required to investigate their function. Taken together our data provide first-time evidence for the coexistence of a mosaic of phosphorylated Cdc25C species. The combination between splicing and differential phosphorylation adds to the complexity of the Cdc25 network. It is tempting to speculate that this additional level of complexity applies to all members of the Cdc25 family.

\section{$\underline{\text { Acknowledgements }}$}


This work was supported by the CNRS (Centre National de la Recherche Scientifique) and grants from the Association de Recherche contre le Cancer (ARC) and the French National Research Agency (ANR) to MCM. J.B. was supported by fellowships from the French Ministry of Research and La Ligue Nationale Contre le Cancer. We thank J.M. Donnay and J.-C. Mazur from the CRBM animal core facility for immunizations. We thank B. Ducommun, V. Baldin, P. Coopman, D. Fesquet, V. Dulic, and all members of the Cell Cycle department of the CRBM for fruitful discussions.

\section{$\underline{\text { References }}$}

[1] D.O. Morgan, Principles of CDK regulation, Nature 374 (1995) 131-134.

[2] J. Pines, C. Rieder, Re-staging mitosis: a contemporary view of mitotic progression, Nat Cell Biol. 3 (2001) E3-6.

[3] I. Hoffmann, P.R. Clarke, M.J. Marcote, E. Karsenti, G. Draetta, Phosphorylation and activation of human cdc25-C by cdc2-cyclin B and its involvement in the self-amplification of MPF at mitosis, EMBO J. 12 (1993) 53-63.

[4] J.R. Pomerening, E.D. Sontag, J.E. Jr. Ferrell, Building a cell cycle oscillator: hysteresis and bistability in the activation of Cdc2, Nat Cell Biol 5 (2003) 346-351.

[5] M. Jackman, C. Lindon, E.A. Nigg, J. Pines, Active cyclin B1-Cdk1 first appears on centrosomes in prophase, Nat. Cell. Biol. 5 (2003) 143-148.

[6] J. E. Jr. Ferrell, Self-perpetuating states in signal transduction: positive feedback, doublenegative feedback and bistability, Curr Opin Cell Biol 14 (2002) 140-148.

[7] J.A Perry, S. Kornbluth, Cdc25 and Wee1: analogous opposites ?, Cell. Div. 4 (2007) 2:12.

[8] R. Boutros, C. Dozier, B. Ducommun B, The when and wheres of CDC25 phosphatases, Curr. Opin. Cell. Biol. 18 (2006) 185-191. 
[9] C. Lammer, S. Wagerer, R. Saffrich, D. Mertens, W. Ansorge, I. Hoffmann, The cdc25B phosphatase is essential for the G2/M phase transition in human cells, J.Cell Sci. 111 (1998) 24452453.

[10] C. Karlsson, S. Katich, A. Hagting, I. Hoffmann, J.Pines, Cdc25B and Cdc25C differ markedly in their properties as initiators of mitosis, J.Cell.Biol. 146 (1999) 573-583.

[11] S. Dutertre, M. Cazales, M. Quaranta, C. Froment, V. Trabut, C. Dozier, G. Mirey, J.P. Bouché, N. Theis-Febvre, E. Schmitt, B. Monsarrat, C. Prigent, B. Ducommun, Phosphorylation of CDC25B by Aurora-A at the centrosome contributes to the G2-M transition, J Cell Sci. 117 (2004) $2523-2531$

[12] A. Lindqvist, H. Källström, A. Lundgren, E. Barsoum, C. Karlsson Rosenthal. Cdc25B cooperates with Cdc25A to induce mitosis but has a unique role in activating Cyclin B1-Cdk1 at the centrosome, J.Cell Biol. 171 (2005) 35-45.

[13] K. Sadhu, S.I. Reed, H. Richardson, P. Russell, human homolog of fission yeast cdc25 mitotic inducer is predominantly expressed in G2, Proc Nat Acad Sci USA 87 (1990) 5139-5143.

[14] J.R.A. Hutchins, P.R. Clarke, Many Fingers on the Mitotic Trigger: Post-Translational Regulation of the Cdc25C Phosphatase. Cell Cycle. 3 (2004) 41-45.

[15] C.Y. Peng, Graves, P.R., Thoma, R.S., Wu, Z., Shaw, A.S., H. Piwnica-Worms, Mitotic and G2 checkpoint control: regulation of 14-3-3 protein binding by phosphorylation of $\mathrm{Cdc} 25 \mathrm{C}$ on serine-216. Science 277 (1997) 1501-1505.

[16] C.Y., Peng, Graves, P.R., Ogg, S., Thoma, R.S., Byrnes 3rd, M.J., Wu, Z., Stephenson, M.T., Piwnica-Worms, H, C-TAK1 protein kinase phosphorylates human Cdc25C on serine 216 and promotes 14-3-3 protein binding. Cell Growth Differ. 9 (1998) 197-208.

[17] S.N., Dalal, C.M. Schweitzer, J. Gan, J.A. DeCaprio, Cytoplasmic localization of human cdc25C during interphase requires an intact 14-3-3 binding site. Mol Cell Biol. 19 (1999) 44654479. 
[18] D.V. Bulavin, Y. Higashimoto, Z.N. Demidenko, S. Meek, P. Graves, C. Phillips, H. Zhao, S.A. Moody, E. Appella, H. Piwnica-Worms, A.J. Jr Fornace, Dual phosphorylation controls Cdc25 phosphatases and mitotic entry, Nat Cell Biol. 5 (2003) 545-51.

[19] U. Strausfeld, A. Fernandez, J.P. Capony, F. Girard, N. Lautredou, J. Derancourt, J.C. Labbe, N.J. Lamb, Activation of $\mathrm{p} 34 \mathrm{cdc} 2$ protein kinase by microinjection of human cdc $25 \mathrm{C}$ into mammalian cells. Requirement for prior phosphorylation of $\operatorname{cdc} 25 \mathrm{C}$ by $\mathrm{p} 34 \mathrm{cdc} 2$ on sites phosphorylated at mitosis, J. Biol. Chem. 269 (1994) 5989-6000.

[20] A.K. Roshak, E.A Capper, C. Imburgia , J. Fornwald, G. Scott , L.A. Marshall, The human polo-like kinase, PLK, regulates cdc2/cyclin B through phosphorylation and activation of the cdc25C phosphatase, Cell Signal. 12 (2000) 405-411.

[21] B.G. Gabrielli, J.M. Clark, A.K. McCormack, K.A.O. Ellem, Hyperphosphorylation of the Nterminal Domain of Cdc25 regulates activity toward Cyclin B1/cdc2 but not cyclin A/cdk2, J. Biol. Chem. 272 (1997) 28607-28614.

[22] R. Patel, M. Holt, R. Philipova , Moss S, Schulman H, Hidaka H, Whitaker M, Calcium/calmodulin-dependent phosphorylation and activation of human $\mathrm{Cdc} 25-\mathrm{C}$ at the G2/M phase transition in HeLa cells. J. Biol. Chem. 274 (1999) 7958-7968.

[23] S.S Margolis, S. Walsh, D.C Weiser, M. Yoshida, S. Shenolikar, S. Kornbluth, PP1 control of M phase entry exerted through 14-3-3-regulated Cdc25 dephosphorylation, EMBO J. 22 (2003) 5734-5745.

[24] S.S Margolis, J.A. Perry, D.H. Weitzel, C.D. Freel, M. Yoshida, T.A. Haystead, S. Kornbluth, A role for PP1 in the Cdc2/Cyclin B-mediated positive feedback activation of Cdc25, Mol Biol Cell. 17 (2006) 1779-1789.

[25] S.S Margolis, J.A. Perry, C.M. Forester, L.K. Nutt, Y. Guo, M.J. Jardim, M.J. Thomenius, C.D. Freel, R. Darbandi, J.H. Ahn, J.D.Arroyo, X.F. Wang, S. Shenolikar, A.C. Nairn, W.G. 
Dunphy, W.C. Hahn, D.M. Virshup, S. Kornbluth, Role for the PP2A/B56delta phosphatase in regulating 14-3-3 release from Cdc25 to control mitosis, Cell 127 (2006) 759-773.

[26] T. Izumi, D.H., Walker, J.L. Maller, .Periodic changes in phosphorylation of the Xenopus cdc25 phosphatase regulate its activity. Mol Biol Cell. 8 (1992) 927-39.

[27] S. Wegener, W. Hampe, D. Herrmann, H.C. Schaller, Alternative splicing in the regulatory region of the human phosphatases CDC25A and CDC25C, Eur. J. Cell. Biol. 79 (2000) 810-815.

[28] M. Bureik, N. Rief, R. Drescher, A. Jungbluth, M. Montenarh, P. Wagner, An additional transcript of the cdc25C gene from A431 cells encodes a functional protein, Int. J. Oncol. 17 (2000) 1251-1258.

[29] S. Hernandez, X. Bessa, S. Bea, L. Hernandez, A. Nadal, C. Mallofre, J. Muntane, A. Castells, P.L. Fernandez, A. Cardesa, E. Campo, Differential expression of cde25 cell-cycle-activating phosphatases in human colorectal carcinoma, Lab. Investig. 81 (2001) 465-473

[30] M. Ozen, M. Ittmann, Increased expression and activity of CDC25C phosphatase and an alternatively spliced variant in prostate cancer, Clin. Cancer Res. 11(2005) 4701-4706.

[31] T.R. Pacheco, F.F. Moita, A.Q. Gomes, N. Hacohen, M. Carmo-Fonseca, RNA interference knockdown of hU2AF35 impairs cell cycle progression and modulates alternative splicing of Cdc25 transcripts, Mol Biol Cell. 17 (2006) 4187-99.

[32] V. Baldin , C. Cans, G. Superti-Furga, B. Ducommun, Alternative splicing of the human CDC25B tyrosine phosphatase. Possible implications for growth control?, Oncogene 14 (1997) 2485-2495.

[33] A.R. Forrest, A.K. McCormack, C.P. DeSouza, J.M. Sinnamon, I.D. Tonks, N.K. Hayward, K.A. Ellem, B.G. Gabrielli, Multiple splicing variants of cdc25B regulate G2/M progression, Biochem Biophys Res Commun. 260 (1999) 510-515.

[34] R. Boutros, V. Lobjois, B. Ducommun, CDC25 phosphatases in cancer cells: key players? Good targets?, Nat. Rev. Cancer. 7 (2007) 495-507. Review. 


\section{Figure Legends}

\section{Fiqure 1: Identification of multiple Cdc25C variants in interphasic and mitotic HeLa cells.}

(A) Interphasic ( lanes A, B, C) or Mitotic (lanes D, E, F) Hela cells either untreated (A, D), or treated with control siRNA (B,E) or with siRNA targeting Cdc25C (C, F). (B) Mitotic extracts were either untreated (-) or treated with Lambda phosphatase (+).Loading control under each panel: amido-black staining.

Fiqure 2: Antibodies raised against phospho-epitopes of Cdc25C specifically recognize phosphoproteins in mitotic extracts.

(A) anti-pThr130 Cdc25C (B) anti-pSer214 (C) anti pThr48. For each panel: Left: Western blots of interphasic (I) and mitotic (M) Hela cell extracts. Right: Mitotic extracts either untreated (-) or treated with Lambda phosphatase $(+)$. Loading control under each panel: amido-black staining.

\section{Fiqure 3: Coexistence of differentially phosphorylated species of Cdc25C in mitotic extracts.}

HeLa cells were treated with control siRNA (Ctrl) or with siRNA targeting Cdc25C (25C) for 48h, then synchronized in mitosis with nocodazole, and cell extracts were probed with the phosphospecific Cdc25C antibodies. (A) Anti-pThr130 (B) Anti-pSer214 (C) Anti-pThr 48. AntipSer214 and anti-pThr48 recognize non-specific high molecular weight phosphoproteins (marked by an asterisk). Loading control under each panel: amido-black staining. (D) Alignment of the Nterminal domains of human $\mathrm{Cdc} 25 \mathrm{C}$ splice variants highlighting mitotic phosphorylation sites (boxed residues).

Figure 4: Schematic representation of the different species of Cdc25C.

Mammalian cells harbour several forms of Cdc25C phosphatase, including a full-length form known as $\mathrm{Cdc} 25 \mathrm{C} 1$, and several splice variants, $\mathrm{Cdc} 25 \mathrm{C} 2, \mathrm{C} 3, \mathrm{C} 4$ and $\mathrm{C} 5$, which may undergo differential phosphorylation on several phosphorylation sites, in particular Ser216 during interphase, Thr48, 67, 130 and Ser130, 214 in mitosis. 
A

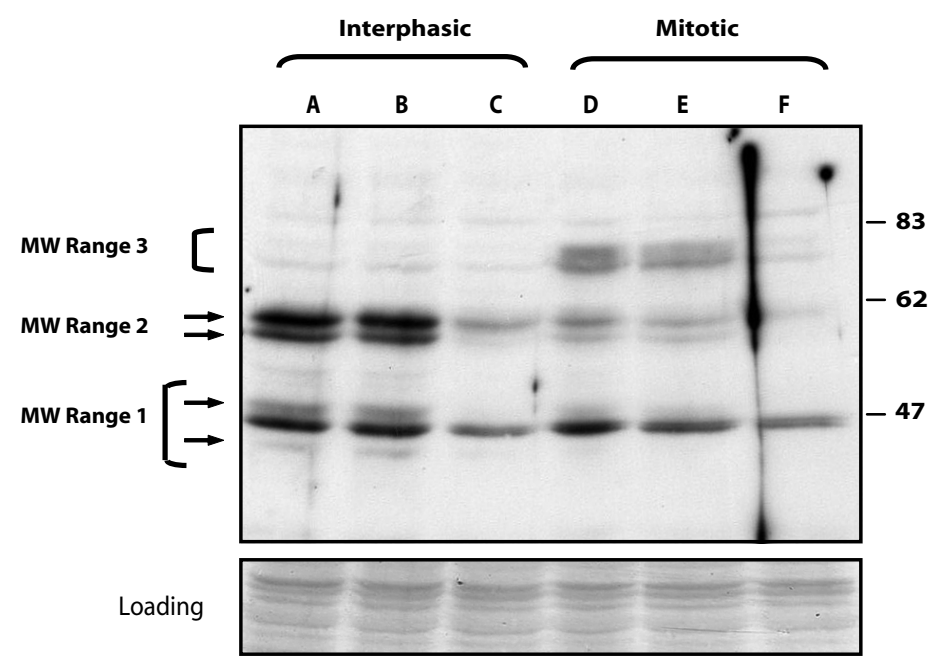

Total Cdc25C (C20)
B

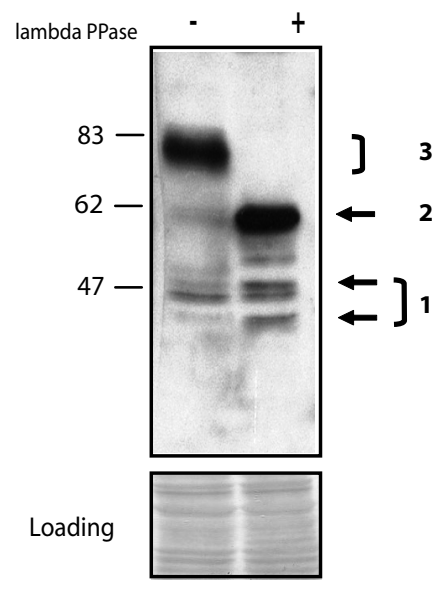


Figure 2

A
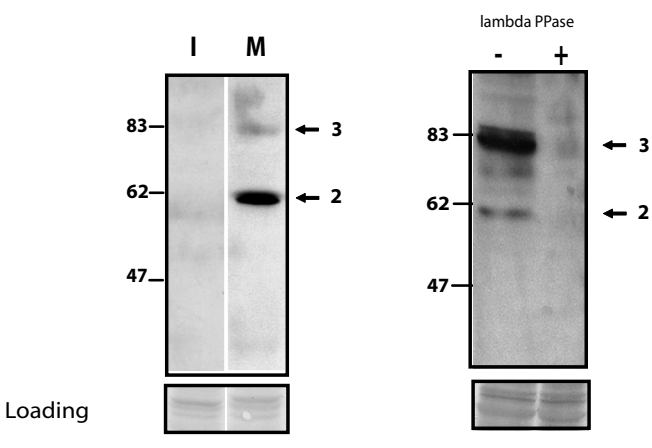

anti-pThr130
B

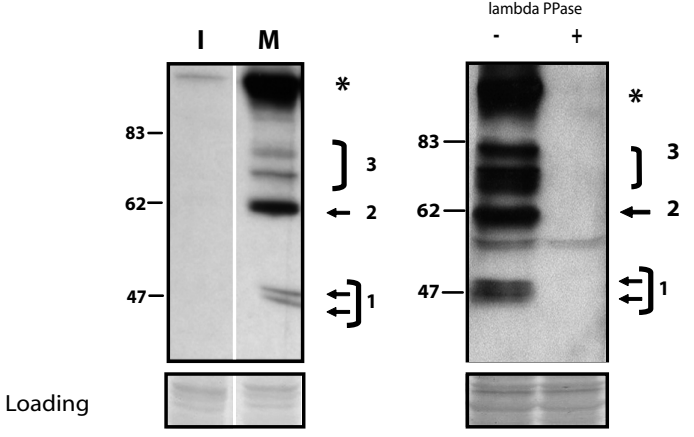

anti-pSer214

C

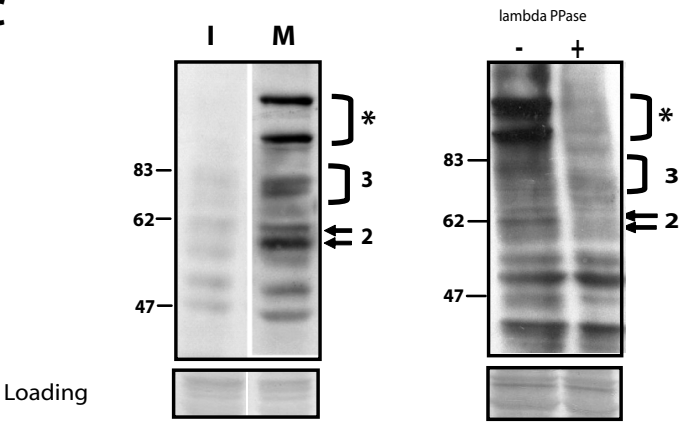

anti-pThr48 


\section{Figure 3}

A

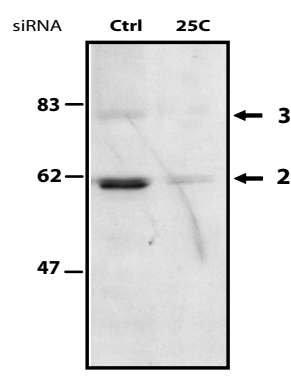

Loading

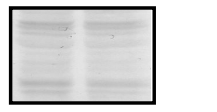

anti-pThr130
B

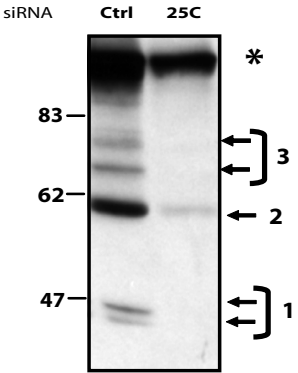

Loading

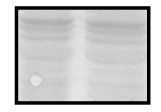

anti-pSer214
C

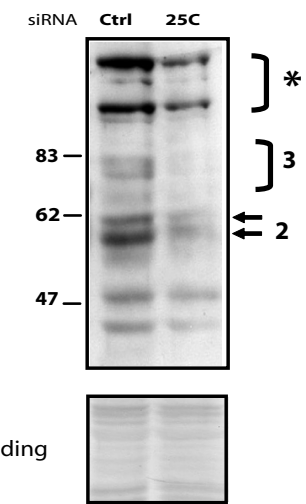

anti-pThr48

$\mathrm{D}$

hCdc25C1 MSTELFSSTREEGSSGSGPSFRSNQRKMLNLLLERDTSFTVCPDVPFTPVGKFLGDSANL 60 hCdc25C2 MSTELFSSTREEGSSGSGPSFRSNQRKMLNLLLERDTSFTVCPDVPATPVGKFLGDSANL 60 hCdc25C3 MSTELFSSTREEGSSGSGPSFRSNQRKMLNLLLERDTSFTVCPDVPATPVGKKFLDSSANL 60 hCdc25C4 MSTELFSSTREEGSSGSGPSFRSNQRKMLNLLLERDTSFTVCPDVPATPVGGKFLGDSANL 60 hCdc25C5 MSTELFSSTREEGSSGSGPSFRSNQRKMLNLLLERDTSFTVCPDVPATPVVGKFLGDSANL 60

hCdc25C1 SILSGTTPKRCLDLSNLSSGEITATQLTTSADLDETGHLDSSGLQEVHLAGMNHDQHLMK 120 hCdc25C2 SILSG TPKRCLDLSNLSSGEITATQLTTSADLDETGHLDSSGLQEVHLAGMNHDQHLMK 120 hCdC25C3 SILSGGTPKCCLDLSNLSSGEITATQLTTSADLDETGHLDSSGLQEVHLAGMTMETWWTV 120 hCdc25C4 SILSG-SP GFFRTSG--SAFSWD --------------------------- 80 hCdc25C5 SILSG-SPGFFRTSG--SAFSWD-

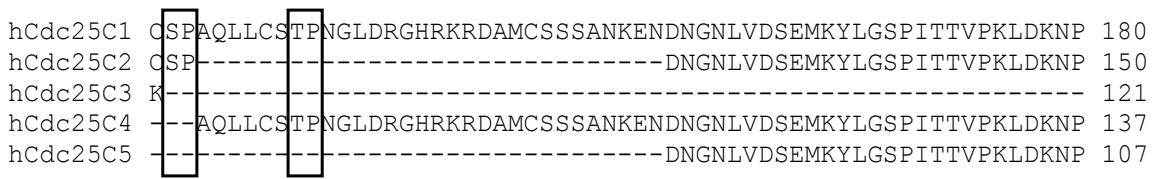

hCdC25C1 NLGEDQAEEISDELMEFSLKDQEAKVSRSGLYY SPSMPENLNRPRLKQVEKFKDNTIPDK 240 hCdc25C2 NLGEDQAEEISDELMEFSLKDQEAKVSRSGLYASPS MPENLNRPRLKQVEKFKDNTIPDK 210 $\mathrm{hCdc} 25 \mathrm{C} 3-$

hCdc25C4 NLGEDQAEEISDELMEFSLKDQEAKVSRSGLYASPSMPENLNRPRLKQVEKFKDNTIPDK 197 hCdc25C5 NLGEDQAEE ISDELMEFSLKDQEAKVSRSGLYASPS MPENLNRPRLKQVEKFKDNTIPDK 167 
Figure 4

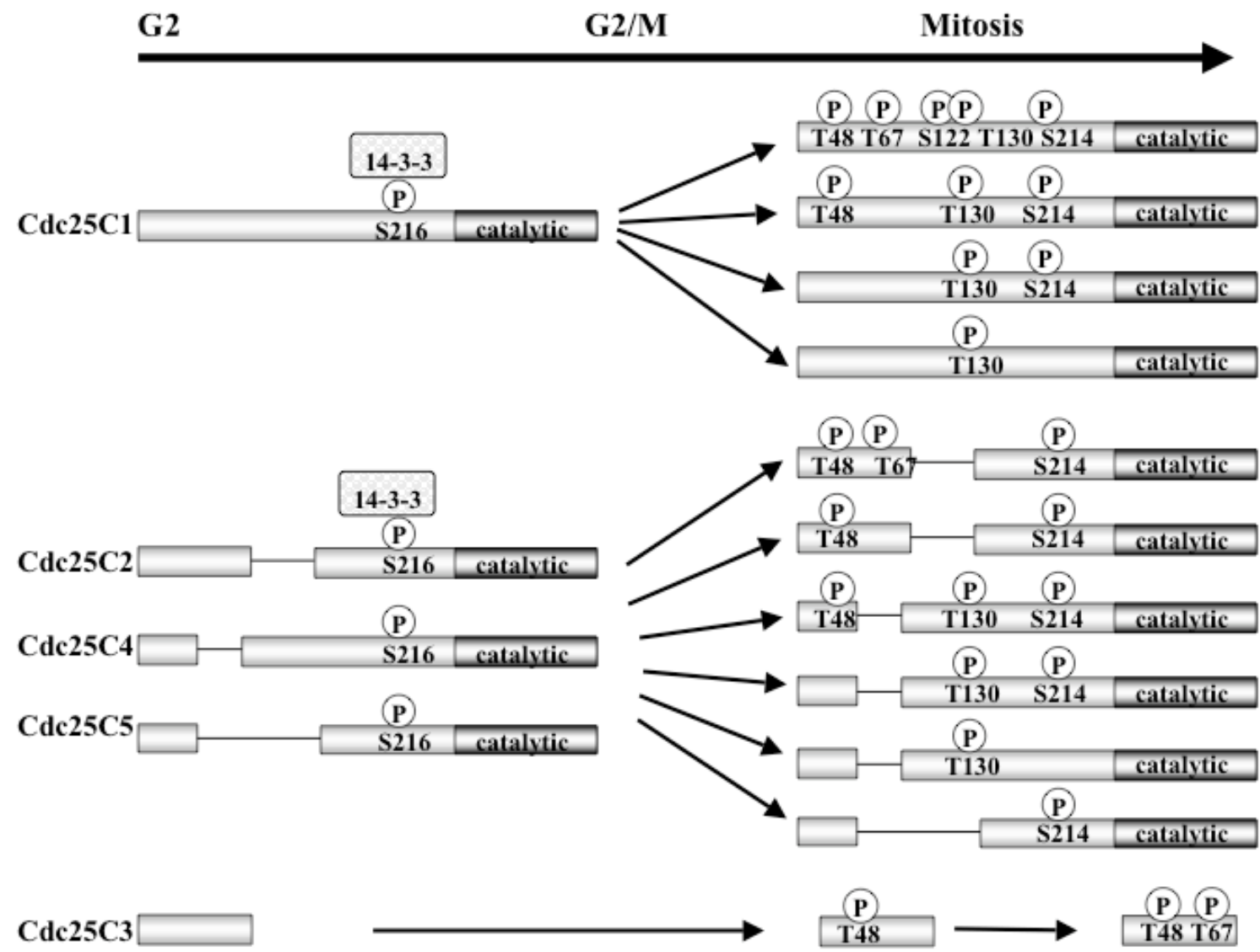

